\title{
Penggunaan Model Pembelajaran Picture and Picture untuk Meningkatkan Hasil Belajar Matematika Anak Tunadaksa Kelas II SDLB
}

\author{
Sri Suryati ${ }^{1}$ \\ ${ }^{1}$ SLBN Prof. Dr. Sri Soedewi Masjchun Sofwan, S.H Jambi, Indonesia \\ Email: suryatisri262@gmail.com
}

\section{INFORMASI ARTIKEL}

Terkirim 13-Oktober-2021

Revisi 21-Oktober-2021

Diterima 26-Oktober -2021

Kata kunci:

Picture and picture, hasil

belajar, matematika,

tunadaksa

\begin{abstract}
ABSTRAK
Penelitian ini bertujuan untuk mengetahui penggunaan model pembelajaran Picture and Picture dalam meningkatkan hasil belajar matematika anak tunadaksa kelas II SDLB Prof. Dr. Sri Soedewi. MS, SH Jambi dan untuk mengetahui aktivitas belajar anak tunadaksa melalui penggunaan model pembelajaran Picture and Picture pada pembelajaran matematika kelas II SDLB Prof. Dr. Sri Soedewi. MS, SH Jambi. Metode yang digunakan adalah Penelitian Tindakan Kelas dengan terdiri dari 5 peserta didik. Penelitian ini dilaksanakan dalam dua siklus. Adapun teknik pengumpulan data adalah menggunakan observasi dan wawancara. Hasil penlitian menunjukkan bahwa terjadi peningkatan kemampuan dalam hasil belajar matematika. Mulai dari kegiatan awal, inti dan akhir pada siklus I dan II terjadi peningkatan dengan persentase yang cukup baik.
\end{abstract}

(i) (2) This is an open access article distributed under the Creative Commons 4.0 Attribution License, This license lets others remix, tweak, and build upon your work even for commerci purposes, as long as they credit you and license their new creations under the identical terms @2018 by author and Universitas Negeri Padang.

\section{Pendahuluan}

Masa kanak-kanak adalah masa yang terindah dalam hidup dimana semua terasa menyenangkan serta terasa tiada beban. Namun tidak semua anak dapat memiliki kesempatan untuk menikmati semua hal tersebut, hanya karena mereka berbeda dari anak kebanyakan lainnya. Anak yang lahir dengan kekurangan, baik itu berupa cacat tubuh maupun mental harus mengalami hal yang berbeda serta beban yang lebih berat daripada anak normal lainnya. Mereka harus melakukannya dengan cara mereka yang khusus. Anak berkebutuhan khusus (ABK) adalah mereka yang membutuhkan pendidikan dan layanan khusus terkait dengan kekhususan yang dimiliki, yaitu kelainan fisik, emosional, mental, sosial atau memiliki potensi kecerdasan dan bakat istimewa, agar mereka dapat berkembang dengan optimal sesuai dengan potensi kemanusiaan.

Mata pelajaran matematika adalah salah satu mata pelajaran di sekolah yang sangat penting bagi anak, karena matematika adalah pelajaran yang tidak terlepas dari kehidupan sehari-hari. Kegiatan sehari-hari yang dilakukan oleh manusia selalu menghadirkan konsep matematika seperti menghitung, membagi, menjumlahkan, dan mengurangi. Belajar matematika juga mampu melatih seseorang untuk berpikir logis dan teliti. Cockrof mengemukakan bahwa matematika sangat penting diajarkan kepada anak, karena matematika digunakan dalam berbagai segi kehidupan, semua mata pelajaran memerlukan keterampilan matematika yang sesuai, merupakan sarana komunikasi yang kuat, ringkas dan jelas, dapat digunakan untuk menyajikan informasi dalam berbagai cara, meningkatkan kemampuan berfikir logis, ketelitian dan kesadaran keruangan, memberikan kepuasan terhadap usaha 
memecahkan masalah yang menantang.

Mengingat betapa pentingnya peran matematika yang besar bagi kehidupan manusia, maka matematika harus diajarkan dengan benar dengan menggunakan model-model pembelajaran yang sesuai sehingga anak mempunyai konsep dasar matematika yang benar dan jelas yang mana ilmu matematika ini nantinya akan digunakan dalam berbagai segi kehidupan sehari-hari. Selain itu, faktanya bahwa hampir setiap seleksi, apakah itu seleksi masuk sekolah ke jenjang pendidikan yang lebih tinggi, seleksi mencari pekerjaan selalu ada mata uji matematika. Ini menunjukkan bahwa betapa besar peran matematika dalam berbagai segi kehidupan. Masyarakat awam biasanya beranggapan bahwa anak yang tidak pandai dalam pelajaran matematika adalah siswa yang bodoh. Anggapan tersebut adalah anggapan yang salah karena secara psikologi, kemampuan seseorang bisa dilatih. anak yang kurang pandai dalam pelajaran matematika adalah yang mengalami kesulitan dalam belajar. Kesulitan belajar bisa disebabkan oleh berbagai faktor, tidak hanya disebabkan oleh gangguan sistem saraf (dyscalculia), namun juga disebabkan oleh kurangnya kualitas materi, metode pembelajaran yang mekanistik, dan model pembelajaran yang tidak sesuai sehingga anak sulit memahami konsep matematika. Akibatnya, hasil belajar anak rendah.

Belajar matematika bagi anak SDLB Tunadaksa barangkali tidak semudah anak-anak SD pada umumnya, karena anak SDLB tunadaksa dengan segala kekurangannya seperti kesulitan mobilitas gerak, sebagian punya gangguan motorik, kemampuan inteligensi yang pada umumnya di bawah ratarata, dan lain-lain. Berdasarkan pendapat ini penulis meyakini bahwa faktor eksternal yang berupa media pembelajaran sangat menentukan hasil belajar anak. Selama observasi kurang lebih tiga bulan ini penulis melihat bahwa guru kelas II SDLB tunadaksa tersebut tidak pernah menggunakan media pembelajaran dalam mengajar matematika. Selain itu juga, guru tidak menggunakan model pembelajaran tertentu. Guru hanya menggunakan metode pembelajaran konvensional seperti ceramah dan tanya jawab. Guru hanya menjelaskan materi secara lisan, terulis di papan tulis, guru juga tidak menggunakan media pembelajaran, hanya terpaku pada buku teks. Di bulan pertama guru tidak menggunakan media pembelajaran dan juga model pembelajaran tertentu. Waktu itu penulis berfikir barang kali di bulan kedua guru akan menggunakan media, ternyata bulan kedua dan ketiga juga tidak menggunakan media pembelajaran. Padahal fungsi media itu sangat penting dalam pembelajaran.

Soeparno mengatakan bahwa media adalah suatu alat yang dipakai sebagai saluran (channel) untuk menyampaikan suatu pesan (message) atau informasi dari suatu sumber (resource) kepada penerimanya (resceiver). Jadi, media adalah suatu alat perlengkapan yang dapat membantu komunikasi antara pihak satu dengan pihak lain. Tujuan utama penggunaan media adalah agar pesan atau informasi yang dikomunikasikan tersebut dapat diserap semaksimal mungkin oleh para siswa sebagai penerima informasi. Agar tujuan komunikasi penggunaan media yang diinginkan dapat tercapai dengan baik. Kehadiran media tidak hanya sebagai alat bantu pembelajaran tetapi merupakan bagian integral dalam proses pembelajaran. Kedudukan media pengajaran ada dalam komponen metode mengajar sebagai salah satu upaya untuk mempertinggi proses interaksi guru-siswa dan interaksi siswa dengan lingkungan belajarnya. Fungsi utama dari media pembelajaran adalah sebagai alat bantu mengajar, yakni menunjang penggunaan metode mengajar yang dipergunakan guru. Melalui penggunaan media pengajaran diharapkan dapat mempertinggi kualitas proses belajar mengajar yang 
pada akhirnya dapat meningkatkan hasil belajar siswa.

Berdasarkan uraian di atas, penulis berpendapat bahwa salah satu penyebab rendahnya hasil belajar matematika pada anak kelas II SDLB tunadaksa adalah karena guru dalam mengajar hanya menjelaskan materi secara lisan (ceramah), terulis di papan tulis, guru juga tidak menggunakan media pembelajaran, hanya terpaku pada buku teks. Selain itu guru dalam mengajar tidak menggunakan model pembelajaran tertentu yang sesuai yang bisa membangkitkan minat dan motivasi belajar siswa serta bisa membantu siswa dalam memahami materi pembelajaran.

Banyak penelitian yang berkaitan dengan penggunaan model pembelajaran Picture and Picture diantaranya adalah penelitian yang dilakukan oleh Endah Ayu Marlupy. Hasil penelitian yang telah dilakukan menunjukkan bahwa terdapat pengaruh yang signifikan terhadap kemampuan menyikat gigi setelah menggunakan model pembelajaran Picture and Picture. Hasil penelitian tersebut menginspirasi penulis untuk mencobakan model pembelajaran Picture and Picture terhadap pelajaran matematika terutama dalam penjumlahan.

Berpedoman pada latar belakang masalah yang telah dipaparkan di atas, maka dapat diambil rumusan masalah sebagai berikut: "Bagaimana peningkatan aktivitas belajar matematika anak tunadaksa melalui penggunaan model pembelajaran Picture and Picture kelas II SDLB Prof. Dr. Sri Soedewi. MS, SH Jambi?" dan "Bagaimana peningkatan hasil belajar matematika anak tunadaksa melalui penggunaan model pembelajaran Picture and Picture kelas II SDLB Prof. Dr. Sri Soedewi. MS, SH Jambi?".

Tujuan dalam penelitian ini adalah untuk mengetahui penggunaan model pembelajaran Picture and Picture dalam meningkatkan hasil belajar Matematika anak tunadaksa kelas II SDLB Prof. Dr. Sri Soedewi. MS, SH Jambi dan untuk mengetahui aktivitas belajar anak tunadaksa melalui penggunaan model pembelajaran Picture and Picture pada pembelajaran matematika kelas II SDLB Prof. Dr. Sri Soedewi. MS, SH Jambi.

\section{Metode}

Jenis penelitian ini adalah Penelitian Tindakan Kelas (PTK) dengan menggunakan desain penelitian model Kemmis dan Mc. Taggart. Penelitian ini sendiri menggunakan 2 siklus dalam prosesnya. Subjek penelitian ini adalah peserta didik kelas II SDLB Prof. Dr. Sri Soedewi. MS, SH Jambi yang terdiri dari 5 peserta didik. Objek penelitian adalah keaktifan belajar peserta didik. Teknik pengumpulan data menggunakan observasi dan wawancara. Data dianalisis secara deskriptif dan disajikan dalam bentuk tabel.

\section{Hasil Penelitian dan Pembahasan}

Berdasarkan pelaksanaan tindakan selama 2 siklus yang dilakukan sebanyak 4 kali pertemuan, diperoleh data bahwa keaktifan belajar siswa mengalami peningkatan. Peningkatan keaktifan belajar diketahui dengan menerapkan penggunaan model pembelajaran Picture and Picture. Hasil observasi terhadap penerapan model pembelajaran Picture and Picture dapat dilihat pada diagram berikut: 
Tabel I. Perbandingan Hasil Observasi Keaktifan Belajar Siswa Menggunakan Model pembelajaran Picture and Picture siklus I dan siklus II

\begin{tabular}{cc}
\hline Keaktifan Belajar Siswa Menggunakan Model pembelajaran Picture and Picture \\
\hline Siklus I & Siklus II \\
\hline $53,2 \%$ & $58,9 \%$ \\
\hline Cukup Baik & Baik
\end{tabular}

Berdasarkan tabel di atas persentase hasil observasi keaktifan belajar siswa menggunakan model pembelajaran Picture and Picture pada siklus I masih 53,2\% dengan kategori cukup baik, sedangkan pada siklus II mencapai 58,9\% dengan kategori baik. hasil observasi keaktifan belajar siswa menggunakan model pembelajaran Picture and Picture meningkat dari siklus I ke siklus II sebesar 5,7\%. Peningkatan keaktifan belajar siswa diketahui dari hasil evaluasi siswa pada siklus I dan II sebagai berikut:

Tabel 2. Data Hasil Evaluasi Peserta Didik Siklus I dan II

\begin{tabular}{lcc}
\hline \multirow{2}{*}{ Keterangan } & \multicolumn{2}{c}{ Nilai } \\
\cline { 2 - 3 } & Siklus I & Siklus II \\
\hline Jumlah & 250 & 320 \\
\hline Rata-rata & 50 & 64 \\
\hline Nilai Tertinggi & 70 & 70 \\
\hline Tuntas KKM & 1 & 3 \\
\hline Belum Tuntas KKM & 4 & 2 \\
\hline Persentase KKM & $20 \%$ & $60 \%$ \\
\hline
\end{tabular}

Berdasarkan penelitian yang sudah dilaksanakan, diketahui bahwa hasil belajar peserta didik pada pembelajaran Matematika melalui penerapan model Picture and Picture mengalami peningkatan. Rata- rata nila peserta didik meningkat dari siklus I sebesar 53,2 menjadi 58,9 pada siklus II. Berdasarkan data tersebut, diketahui bahwa peserta didik yang telah lolos KKM (Kriteria Ketuntasan Minimum) pada siklus I sebanyak 1 peserta didik dari seluruh jumlah peserta didik dengan persentase $20 \%$. Pada siklus II terjadi peningkatan mencapai $60 \%$ yang terdiri dari 3 peserta didik yang telah lulus KKM. Pencapaian hasil belajar klasikal pada siklus II sudah mencapai indikator keberhasilan karena peserta didik mengalami ketuntasan belajar individual 60\%. Hasil observasi aktivitas guru menggunakan model pembelajaran Picture and Picture pada siklus I dan siklus II disajikan dalam tabel 3 berikut.

Tabel 3. Perbandingan Hasil Observasi Aktivitas Guru menggunakan Menggunakan Model pembelajaran Picture and Picture siklus I dan siklus II

\begin{tabular}{cccccc}
\hline \multicolumn{5}{c}{ Aktivitas Guru Menggunakan Model pembelajaran Picture and Picture } \\
\hline Siklus I & \multicolumn{3}{c}{ Siklus II } \\
\hline Kegiatan Awal & Kegiatan Inti & Kegiatan Akhir & Kegiatan Awal & Kegiatan Inti & Kegiatan Akhir \\
\hline $73,3 \%$ & $64,0 \%$ & $60,0 \%$ & $73,3 \%$ & $68,0 \%$ & $60,0 \%$
\end{tabular}


Hasil observasi keterampilan guru siklus I Kegiatan Awal memperoleh persentase 73,3\% dengan kriteria baik. Siklus I Kegiatan Inti terjadi penurunan skor menjadi 64,0\% dengan kriteria cukup baik. Siklus I Kegiaatan Akhir memperoleh persentase 60,0\% dengan kriteria cukup baik. Pada siklus II Kegiatan Awal memperoleh presentase 73,3\% hasil kriteria baik. Keterampilan guru siklus II Kegiatan Inti memperoleh presentase 68,0\% dengan kriteria cukup baik. Keterampilan guru siklus II Kegiatan Akhir memperoleh Presentase 60,0\% dengan kriteria cukup baik.

Penggunaan model pembelajaran Picture and Picture dalam pembelajaran Matematika membuat pembelajaran Matematika menjadi lebih bermakna, menyenangkan, dan memunculkan keaktifan peserta didik karena model pembelajaran Picture and Picture melibatkan peserta didikberperan aktif untuk menemukan jawaban suatu permasalahan melalui proses berpikir dan diskusi. Model pembelajaran Picture and Picture menitikberatkan siswa aktif secara mental maupun fisik. Aktivitas mental yang dilakukan dalam model pembelajaran Picture and Picture dapat membuat pembelajaran menjadi bermakna dan menyenangkan sehingga mudah diingat peserta didik. dapat disimpulkan bahwa penggunaan model pembelajaran Picture and Picture dapat meningkatkan hasil belajar Matematika anak Tunadaksa Kelas II SDLB Prof. Dr. Sri Soedewi. MS, SH. Jambi.

\section{Kesimpulan}

Berdasarkan hasil penelitian yang telah dilaksanakan, maka dapat disimpulkan bahwa penerapan model pembelajaran Picture and Picture dalam pembelajaran Matematika di kelas II anak Tunadaksa Kelas II SDLB Prof. Dr. Sri Soedewi. MS, SH. Jambi dapat meningkatkan keaktifan belajar peserta didik. Pelaksanaan model pembelajaran Picture and Picture mengalami peningkatan. Rata-rata persentase keaktifan belajar pada pra siklus sebesar 0\% (kategori kurang) meningkat menjadi 20\% (kategori cukup baik) pada siklus I. Penerapan model pembelajaran Picture and Picture pada siklus I terdapat beberapa kekurangan sehingga perlu dilakukan perbaikan pada sikus II. Adapun perbaikan yang dilakukan berupa pemberian petunjuk gambar kepada siswa agar memudahkan siswa dalam berhitung. Guru lebih intensif dalam membimbing siswa. Peneliti dan guru melakukan diskusi mengenai langkah pembelajaran yang belum terlaksana. Setelah dilaksanakan perbaikan, terjadi peningkatan pada siklus II berupa rata-rata persentase keaktifan siswa meningkat menjadi 60\% (kategori baik).

\section{Daftar Rujukan}

Dewi, Frisca, Kumala. (2013). Penerapan Model Picture and Picture untuk Meningkatkan Keterampilan Menulis Deskripsi pada Siswa Kelas II SDN Bringin 02 Semarang. Semarang: Universitas Negeri Semarang.

Dimyati, Johni. (2013). Metodologi Penelitian Pendidikan dan Aplikasinya. Jakarta: Kencana Prenada Media Group.

Hamdani. (2011). Strategi Belajar Mengajar. Bandung: Pustaka Setia.

Huda, Miftahul. (2014). Model-Model Pengajaran dan Pembelajaran, Isu-Isu Metodis dan Paradigmatis. Jakarta: Pusat Pelajar.

Marlupy, E, Ayu. (2015). Pengaruh Metode Picture and Picture Terhadap Kemampuan Menyikat Gigi 
Pada anak Tunagrahita Sedang di SLB YKK Pacitan. Surabaya: Universitas Negeri Surabaya.

Miftachudin. (2011). Peningkatan Keterampilan Menulis Narasi Melalui Model Picture and Picture pada Siswa Kelas III SDN Turi 2 Kota Blitar. Malang : Universitas Negeri Malang.

SLB Prof. Sri Soedewi Masjcun Sofwan, SH Jambi. (2016). Dokumen SLB Prof. Sri Soedewi Masjcun Sofwan, SH Jambi.

- 2016. Dokumen Guru, Daftar Penilaian Guru Tahun Pelajaran 2016.

Werdiyati, Umi. (2012). Meningkatkan Hasil Belajar Dalam Pembelajaran Pengukuran Berat Menggunakan Model Pembelajaran Picture and Picture Pada Siswa Tunagrahita Ringan di SLB Jambi. Jambi: Universitas Jambi. 